Article

\title{
Investigating the Role of Micromammals in the Ecology of Coxiella burnetii in Spain
}

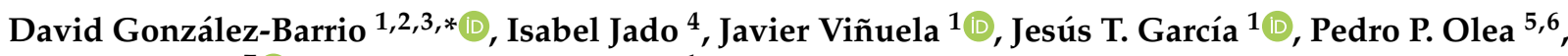 \\ Fernando Arce ${ }^{7}(\mathbb{D})$ and Francisco Ruiz-Fons ${ }^{1, *}$
}

1 Instituto de Investigación en Recursos Cinegéticos IREC (CSIC-UCLM-JCCM), Ronda de Toledo 12, 13071 Ciudad Real, Spain; Javier.Vinuela@uclm.es (J.V.); jesusgarcia.irec@gmail.com (J.T.G.)

2 Parasitology Reference and Research Laboratory, Spanish National Centre for Microbiology, Health Institute Carlos III, Ctra. Majadahonda-Pozuelo Km 2, Majadahonda, 28220 Madrid, Spain

3 Viral Hepatitis Reference and Research Laboratory, Spanish National Centre for Microbiology, Health Institute Carlos III, Ctra. Majadahonda-Pozuelo Km 2, Majadahonda, 28220 Madrid, Spain

4 Special Pathogens Reference and Research Laboratory, Spanish National Centre for Microbiology, Health Institute Carlos III, Ctra. Majadahonda-Pozuelo Km 2, Majadahonda, 28220 Madrid, Spain; ijado@isciii.es

5 Departamento de Ecología, Universidad Autónoma de Madrid (UAM), 28049 Madrid, Spain; pedrop.olea@uam.es

6 Centro de Investigación en Biodiversidad y Cambio Global (CIBC-UAM), Universidad Autónoma de Madrid, 28049 Madrid, Spain

7 School of Natural Sciences, University of Tasmania, Hobart, TAS 7004, Australia; fernando.arcegonzalez@utas.edu.au

* Correspondence: dgonzalezbarrio@gmail.com (D.G.-B.); josefrancisco.ruiz@uclm.es (F.R.-F.)

Citation: González-Barrio, D.; Jado, I.; Viñuela, J.; García, J.T.; Olea, P.P.; Arce, F.; Ruiz-Fons, F. Investigating the Role of Micromammals in the Ecology of Coxiella burnetii in Spain. Animals 2021, 11, 654. https:// doi.org/10.3390/ani11030654

Academic Editors: Julie Arsenault and Marsilio Fulvio

Received: 27 January 2021

Accepted: 23 February 2021

Published: 2 March 2021

Publisher's Note: MDPI stays neutral with regard to jurisdictional claims in published maps and institutional affiliations.

Copyright: (C) 2021 by the authors. Licensee MDPI, Basel, Switzerland. This article is an open access article distributed under the terms and conditions of the Creative Commons Attribution (CC BY) license (https:/ / creativecommons.org/licenses/by/ $4.0 /)$.
Simple Summary: Coxiella burnetii, the causal agent of human $Q$ fever and animal Coxiellosis, is a zoonotic infectious bacterium with a complex ecology that replicates in multiple host species. However, the role of wildlife in its transmission is poorly understood. We examined 816 spleen samples obtained from ten species of micromammals and 130 vaginal swabs from Microtus arvalis females to detect the presence of $C$. burnetii DNA by qPCR. Our aim was assessing whether infection occurs in micromammals in Spain and what species could be relevant hosts in pathogen maintenance. The $9.7 \%$ of the spleen samples were qPCR positive. The infection prevalence level was highest $(10.8 \%)$ in Microtus arvalis and also one vaginal swab was PCR positive. Positive samples were also found in Apodemus sylvaticus (8.7\%), Crocidura russula (7.7\%), and Rattus rattus (6.4\%). A genotype II+ strain was identified in one of the positive samples from $M$. arvalis. The results of the study are consistent with previous findings suggesting susceptibility of micromammals to C. burnetii infection. We also provide further support to consider micromammals when tracing the origin of human $Q$ fever cases in Europe as one of the authors probably got infected while handling M. arvalis.

Abstract: Coxiella burnetii, the causal agent of human $Q$ fever and animal Coxiellosis, is a zoonotic infectious bacterium with a complex ecology that results from its ability to replicate in multiple (in)vertebrate host species. Spain notifies the highest number of Q fever cases to the ECDC annually and wildlife plays a relevant role in C. burnetii ecology in the country. However, the whole picture of C. burnetii hosts is incomplete, so this study seeks to better understand the role of micromammals in C. burnetii ecology in the country. Spleen samples from 816 micromammals of 10 species and 130 vaginal swabs from Microtus arvalis were analysed by qPCR to detect $C$. burnetii infection and shedding, respectively. The $9.7 \%$ of the spleen samples were qPCR positive. The highest infection prevalence (10.8\%) was found in Microtus arvalis, in which C. burnetii DNA was also detected in 1 of the 130 vaginal swabs $(0.8 \%)$ analysed. Positive samples were also found in Apodemus sylvaticus (8.7\%), Crocidura russula (7.7\%) and Rattus rattus (6.4\%). Positive samples were genotyped by coupling PCR with reverse line blotting and a genotype II+ strain was identified for the first time in one of the positive samples from $M$. arvalis, whereas only partial results could be obtained for the rest of the samples. Acute $Q$ fever was diagnosed in one of the researchers that participated in the study, and it was presumably linked to $M$. arvalis handling. The results of the study are consistent with previous 
findings suggesting that micromammals can be infected by C. burnetii. Our findings additionally suggest that micromammals may be potential sources to trace back the origin of human $Q$ fever and animal Coxiellosis cases in Europe.

Keywords: micromammals; Coxiella burnetii; Q fever; zoonosis

\section{Introduction}

Coxiella burnetii is a multi-host bacterium that causes $\mathrm{Q}$ fever in humans, a zoonosis that is emerging worldwide [1]. In humans, $\mathrm{Q}$ fever is associated with a multiple clinical spectrum, from asymptomatic to fatal disease. A low percentage of acute cases, especially patients with previous valvulopathy and, to a lesser extent, immunocompromised persons and pregnant women, develop chronic disease that may present with endocarditis, vascular alterations, chronic hepatitis, chronic pulmonary infections, or the so-called post-Q fever fatigue syndrome [2].

It is assumed that domestic ruminants are the main reservoir of $C$. burnetii for humans. Nonetheless, the origin of several human $Q$ fever cases remains unclarified [3] and human-wildlife interaction has been suggested as a risk factor for human infection with $C$. burnetii [4]. The current changes in the patterns of wildlife-human interactions caused by variations in human and wildlife population dynamics and behaviour imply an increased risk of $C$. burnetii inter-species transmission [4]. The ecology of C. burnetii in wildlife is still poorly understood and the influence of host, environmental and pathogen factors is almost unknown [4]. C. burnetii infection has been neglected in wildlife despite the evidence of particular wild species behaving as true C. burnetii reservoirs [4]. Indeed, scientific publications focused on C. burnetii in livestock outnumber those in wildlife tenfold. The circulation of $C$. burnetii in wild vertebrates in the sylvatic cycle may perhaps be also enhanced by tick-borne transmission [5]. Wild terrestrial small mammals such as rodents are thought to constitute maintenance hosts of infection in the domestic cycle of C. burnetii [6-9].

Within Europe, Spain has reported the highest number of human Q fever cases annually since 2016 (Q fever is of mandatory notification in Spain since 2015). In 2018, Spain accounted for more than a third of the overall number of cases with 418 reported notifications [10]. Livestock (mainly cattle, sheep and goats) is an important reservoir of C. burnetii for humans in Spain [11]. However, the geographical location of the country (between Mediterranean and Atlantic oceanic climates) and its orography account for a wide diversity of habitats and biotopes that make Spain a European biodiversity hotspot. As C. burnetii is a multi-host pathogen by evolution, the implication of wild reservoirs in its life cycle was expected and already reported in different studies [12-14]. The role of wild micromammals such as rodents and insectivores in C. burnetii ecology is currently poorly known. A recent review of studies performed in wild mammals suggests that several micromammal species worldwide may be relevant hosts for C. burnetii [4]. It would be expected that the large diversity of micromammals in Spain would add up with joint effects favouring the proliferation of $C$. burnetii because of the higher host availability. Furthermore, the current expansion of some 'pest' rodent species (e.g., Microtus arvalis) would have an impact in the sylvatic cycle of the bacterium and therefore in the incidence of human $\mathrm{Q}$ fever and animal coxiellosis in the country. A large area in Spain is occupied by farming areas that are in line with the intensification trend of the agriculture in Europe, and it has suffered tremendous transformations in the last 2-3 decades [15]. This transformation is behind the massive spatial expansion and the cyclic population outbreaks of the common vole ( $M$. arvalis) that is considered a severe agricultural pest at European level, a matter of intersectoral conflict and a risk for human and animal health $[15,16]$. Furthermore, the sustained human migration from rural to urban areas over the last four decades in Spain has notably contributed to re-wilding of Iberian forests [17], consequently bearing a re-colonization of lost areas by wildlife, including wild forest micromammals. In both 
agricultural and natural (forested) landscapes in Spain, the (direct and indirect) interaction with humans, grazing livestock and other wildlife may constitute a risk factor for the exchange of specific strains of $C$. burnetii among different hosts.

According to these premises and to the hypothesis of a relevant implication of wild micromammals in C. burnetii ecology in Spain (and beyond), the objectives of this study were to estimate the presence and prevalence of the bacterium in different wild micromammal species and phylogenetically characterize the $C$. burnetii genotypes present in these animals as a first stage to estimate the implication of wild micromammals in the epidemiology of $Q$ fever.

\section{Materials and Methods}

\subsection{Sampling}

Between 2003 and 2014, and in the framework of different studies, samples from wild micromammals were collected in 16 locations in mainland Spain using LFATDG Sherman Live Traps $(7.62 \mathrm{~cm} \times 8.89 \mathrm{~cm} \times 22.86 \mathrm{~cm}, \mathrm{H}$. B. Sherman Traps, Inc., Tallahassee, FL, USA) (Figure 1 and Table 1). Capture and handling procedures for sampling were approved by the UCLM Ethics Committee (reference number CEEA: PR20170201) and were in accordance with the Spanish and European policy for animal protection and experimentation. The researchers and technicians involved in the captures only employed gloves as personal protective equipment. Some of the individuals captured were randomly selected, sedated with an intramuscular injection of a solution containing Ketamin $(10 \mathrm{mg} / \mathrm{kg})$ and medetomidine $(1 \mathrm{mg} / \mathrm{kg})$ and thereafter humanely euthanised by cervical dislocation. These animals were transported refrigerated to our labs where a detailed necropsy was performed under biosafety 2 containment in cabinets, and tissue samples were collected and preserved frozen at $-20^{\circ} \mathrm{C}$. Vaginal swabs (Aluminium + viscose AMIES swabs, Deltalab, Spain) were collected from live female $M$. arvalis captured in northwestern Spain along 2012. The swabs were thereafter preserved frozen at $-20^{\circ} \mathrm{C}$ until DNA purification. Some species (Arvicola terrestris, Sciurus vulgaris and Eliomys quercinus; Table 2) were surveyed after being found dead close to trap capture sites or by environment agents and brought to the lab for necropsy.

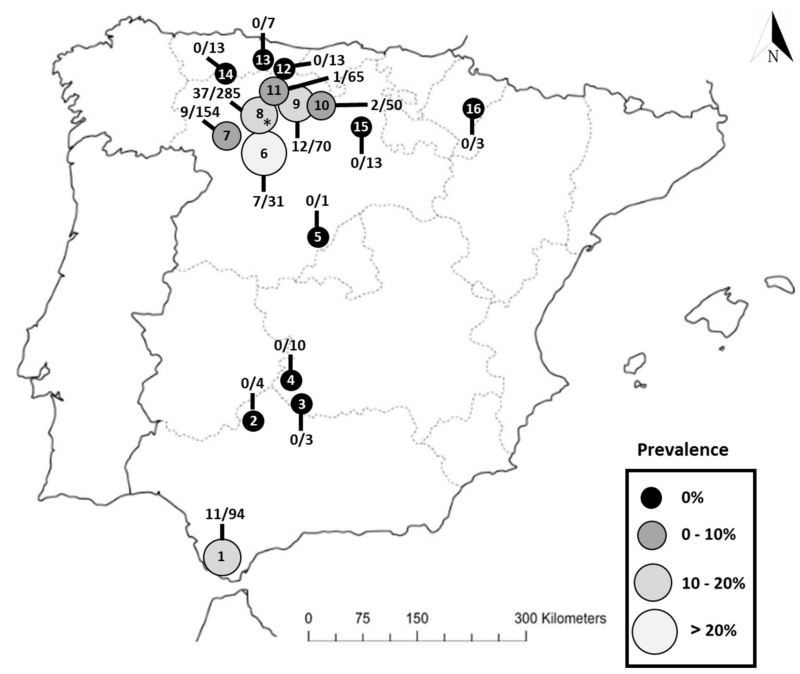

Figure 1. Spatial distribution and prevalence of Coxiella burnetii DNA in spleen samples from micromammals. Each dot (overall sample size included) represents a surveyed population of micromammals. The numbers shown per location indicate the number of positive samples with respect to local sample size (positives/total). The size and color of the dots show population prevalence of $C$. burnetii infection as detailed in the legend. The asterisk $\left(^{*}\right)$ in a dot indicates that a $C$. burnetii genotype was obtained in this population. 


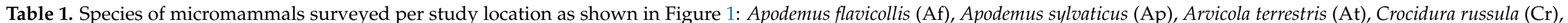

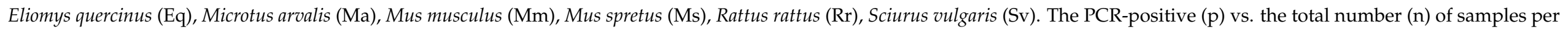

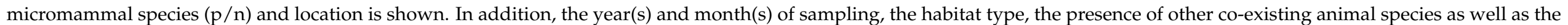
existence of evidence of previous detection of $\mathrm{C}$. burnetii in non-micromammal species in the location are included. n.a. $=$ data not available.

\begin{tabular}{|c|c|c|c|c|c|}
\hline Location Reference & Micromammal Species Surveyed & Sampling Period & Habitat Type & $\begin{array}{l}\text { Co-Habitation with } \\
\text { Other Animals }\end{array}$ & $\begin{array}{l}\text { Previous DNA Detection of } \\
\text { C. burnetii in Other Species }\end{array}$ \\
\hline 1 & $\begin{array}{c}\text { As }(7 / 33), \operatorname{Cr}(1 / 8), \operatorname{Eq}(0 / 2), \mathrm{Ms} \\
(0 / 4), \operatorname{Rr}(3 / 47)\end{array}$ & $\begin{array}{l}2013 \text { (January, June, } \\
\text { July, December) }\end{array}$ & $\begin{array}{l}\text { Natural Mediterranean } \\
\text { scrubland with large } \\
\text { areas of irrigated prairies. }\end{array}$ & Wildlife & Yes $[13,14]$ \\
\hline 2 & As $(0 / 1), \operatorname{Cr}(0 / 2), \operatorname{Ms}(0 / 1)$ & 2003 (April) & $\begin{array}{l}\text { Natural Mediterranean scrubland } \\
\text { with Savannah-like areas }\end{array}$ & Wildlife & Yes $[13,18]$ \\
\hline 3 & As $(0 / 1), \operatorname{Mm}(0 / 2)$ & 2003 (June) & Natural Mediterranean scrubland & Wildlife & Yes [18] \\
\hline 4 & As $(0 / 5), \mathrm{Ms}(0 / 5)$ & 2004 (April) & Natural Mediterranean scrubland & Wildlife & n.a. \\
\hline 6 & As $(0 / 1), \mathrm{Ma}(7 / 30)$ & $\begin{array}{l}2013 \text { (April) } \\
2014 \text { (May) }\end{array}$ & Agricultural areas & Occasionally sheep & n.a. \\
\hline 7 & As $(0 / 18), \mathrm{Ma}(9 / 134), \mathrm{Ms}(0 / 2)$ & 2012 (March-July, October) & Agricultural areas & Occasionally sheep & n.a. \\
\hline 8 & $\begin{array}{c}\text { As }(4 / 45), \operatorname{Cr}(0 / 5) \\
\mathrm{Ma}(33 / 232), \mathrm{Ms}(0 / 3)\end{array}$ & $\begin{array}{c}2012 \text { (January-November) } \\
2013 \text { (March-May) } \\
2014 \text { (May) }\end{array}$ & Agricultural areas & Occasionally sheep & Yes [19] \\
\hline 9 & $\begin{array}{l}\text { As }(1 / 13), \operatorname{Cr}(0 / 2), \\
\mathrm{Ma}(11 / 51), \operatorname{Ms}(0 / 4)\end{array}$ & $\begin{array}{l}2011 \text { (November-December) } \\
2012 \text { (January-April) }\end{array}$ & Agricultural areas & Occasionally sheep & n.a. \\
\hline 11 & $\begin{array}{l}\text { As }(0 / 2) \text {, At }(0 / 1) \\
\text { Cr }(1 / 3), \operatorname{Ma}(0 / 59)\end{array}$ & $\begin{array}{c}2012 \text { (August, September, } \\
\text { November) }\end{array}$ & Agricultural areas & Occasionally sheep & n.a. \\
\hline 12 & As $(0 / 1), \mathrm{Ma}(0 / 12)$ & 2012 (October) & Agricultural areas & $\begin{array}{l}\text { Wildlife and extensive } \\
\text { cattle breeding }\end{array}$ & n.a. \\
\hline 13 & $\operatorname{Af}(0 / 2), \operatorname{As}(0 / 4), \operatorname{Mm}(0 / 1)$ & $\begin{array}{l}2003 \text { (July) } \\
2013 \text { (July) }\end{array}$ & $\begin{array}{l}\text { Atlantic forest interspersed with } \\
\text { scrublands and prairies }\end{array}$ & $\begin{array}{l}\text { Wildlife and extensive } \\
\text { cattle breeding }\end{array}$ & Yes [19] \\
\hline 14 & $\mathrm{Cr}(0 / 3), \mathrm{Ma}(0 / 10)$ & 2012 (August) & $\begin{array}{l}\text { Atlantic forest interspersed with } \\
\text { scrublands and prairies }\end{array}$ & $\begin{array}{l}\text { Wildlife and extensive } \\
\text { cattle breeding }\end{array}$ & n.a. \\
\hline 15 & As (0/10), $\mathrm{Cr}(0 / 1), \mathrm{Mm}(0 / 2)$, & 2003 (June) & $\begin{array}{l}\text { Atlantic forest interspersed with } \\
\text { scrublands and prairies } \\
\text { Steppe and }\end{array}$ & Wildlife & n.a. \\
\hline 16 & $\operatorname{Cr}(0 / 1), \mathrm{Ms}(0 / 2)$ & 2012 (December) & $\begin{array}{c}\text { Mediterranean vegetation } \\
\text { ("Bardenas Reales") }\end{array}$ & Wildlife & Yes [13] \\
\hline
\end{tabular}


Table 2. qPCR results by micromammal species object of survey in this study for each location. Species are displayed along with sample size $(n)$ and the number of qPCR positive samples (PCR positives). In addition, 95\% exact confidence intervals are shown within brackets.

\begin{tabular}{|c|c|c|c|c|}
\hline Location Reference & Species & $n$ & PCR Positives & $\%$ PCR Positive \\
\hline \multirow{5}{*}{1} & Apodemus sylvaticus & 33 & 7 & $21.2(10.7-37.8)$ \\
\hline & Crocidura russula & 8 & 1 & $12.5(2.2-47.1)$ \\
\hline & Eliomys quercinus & 2 & 0 & $0.0(0.0-65.8)$ \\
\hline & Mus spretus & 4 & 0 & $0.0(0.0-48.9)$ \\
\hline & Rattus rattus & 47 & 3 & $6.38(2.2-17.2)$ \\
\hline \multirow{3}{*}{2} & Apodemus sylvaticus & 1 & 0 & $0.0(0.0-79.3)$ \\
\hline & Crocidura russula & 2 & 0 & $0.0(0.0-65.8)$ \\
\hline & Mus spretus & 1 & 0 & $0.0(0.0-79.3)$ \\
\hline \multirow{2}{*}{3} & Apodemus sylvaticus & 1 & 0 & $0.0(0.0-79.3)$ \\
\hline & Mus musculus & 2 & 0 & $0.0(0.0-65.8)$ \\
\hline \multirow[b]{2}{*}{4} & Apodemus sylvaticus & 5 & 0 & $0.0(0.0-43.4)$ \\
\hline & Mus spretus & 5 & 0 & $0.0(0.0-43.4)$ \\
\hline 5 & Sciurus vulgaris & 1 & 0 & $0.0(0.0-79.3)$ \\
\hline \multirow{2}{*}{6} & Apodemus sylvaticus & 1 & 0 & $0.0(0.0-79.3)$ \\
\hline & Microtus arvalis & 30 & 7 & $23.3(11.8-40.9)$ \\
\hline \multirow{3}{*}{7} & Apodemus sylvaticus & 18 & 0 & $0.0(0.0-17.6)$ \\
\hline & Microtus arvalis & 134 & 9 & $6.7(3.6-12.3)$ \\
\hline & Mus spretus & 2 & 0 & $0.0(0.0-65.8)$ \\
\hline \multirow{4}{*}{8} & Apodemus sylvaticus & 45 & 4 & $8.9(3.5-20.7)$ \\
\hline & Crocidura russula & 5 & 0 & $0.0(0.0-43.4)$ \\
\hline & Microtus arvalis & 232 & 33 & $14.2(10.3-19.3)$ \\
\hline & Mus spretus & 3 & 0 & $0.0(0.0-56.1)$ \\
\hline \multirow{4}{*}{9} & Apodemus sylvaticus & 13 & 1 & $7.7(13.7-33.3)$ \\
\hline & Crocidura russula & 2 & 0 & $0.0(0.0-65.8)$ \\
\hline & Microtus arvalis & 51 & 11 & $21.6(12.5-34.6)$ \\
\hline & Mus spretus & 4 & 0 & $0.0(0.0-48.9)$ \\
\hline \multirow{4}{*}{10} & Apodemus sylvaticus & 4 & 0 & $0.0(0.0-48.9)$ \\
\hline & Crocidura russula & 1 & 0 & $0.0(0.0-79.3)$ \\
\hline & Microtus arvalis & 44 & 2 & $4.5(1.3-15.1)$ \\
\hline & Mus spretus & 1 & 0 & $0.0(0.0-79.3)$ \\
\hline \multirow{4}{*}{11} & Apodemus sylvaticus & 2 & 0 & $0.0(0.0-65.8)$ \\
\hline & Arvicola terrestris & 1 & 0 & $0.0(0.0-79.3)$ \\
\hline & Crocidura russula & 3 & 1 & $33.3(6.1-79.2)$ \\
\hline & Microtus arvalis & 59 & 0 & $0.0(0.0-6.1)$ \\
\hline \multirow{2}{*}{12} & Apodemus sylvaticus & 1 & 0 & $0.0(0.0-79.3)$ \\
\hline & Microtus arvalis & 12 & 0 & $0.0(0.0-24.2)$ \\
\hline \multirow{3}{*}{13} & Apodemus flavicollis & 2 & 0 & $0.0(0.0-65.8)$ \\
\hline & Apodemus sylvaticus & 4 & 0 & $0.0(0.0-48.9)$ \\
\hline & Mus musculus & 1 & 0 & $0.0(0.0-79.3)$ \\
\hline \multirow{2}{*}{14} & Crocidura russula & 3 & 0 & $0.0(0.0-56.1)$ \\
\hline & Microtus arvalis & 10 & 0 & $0.0(0.0-27.7)$ \\
\hline \multirow{3}{*}{15} & Apodemus sylvaticus & 10 & 0 & $0.0(0.0-27.7)$ \\
\hline & Crocidura russula & 1 & 0 & $0.0(0.0-79.3)$ \\
\hline & Mus musculus & 2 & 0 & $0.0(0.0-65.8)$ \\
\hline \multirow{2}{*}{16} & Crocidura russula & 1 & 0 & $0.0(0.0-79.3)$ \\
\hline & Mus spretus & 2 & 0 & $0.0(0.0-65.8)$ \\
\hline
\end{tabular}




\subsection{DNA Extraction, Coxiella burnetii DNA Detection and Genotyping}

Spleen samples were the target tissue to estimate the occurrence of infection with C. burnetii because of the presence of C. burnetii DNA in this organ could only be the consequence of a generalized infection. DNA from spleen samples and swabs was extracted by using the DNeasy Blood and Tissue Kit (QIAGEN, Hilden, Germany). Around $25 \mathrm{mg}$ of spleen from each animal was cut into small pieces on a sterile glass plate with a disposable scalpel blade before being disrupted in $180 \mu \mathrm{L}$ of ATL buffer with a homogenizer (TissueLyser II, QIAGEN, Hilden, Germany). After disruption, samples were incubated at $56{ }^{\circ} \mathrm{C}$ for $1 \mathrm{~h}$ with $20 \mu \mathrm{L}$ of Proteinase K. Later on, samples were vortexed for $15 \mathrm{~s}$ and, after adding $200 \mu \mathrm{L}$ of AL buffer, the manufacturer's blood extraction protocol was followed (http://mvz.berkeley.edu/egl/inserts/DNeasy_Blood_\&_Tissue_Handbook. pdfaccessedon14October2020). The swabs were incubated at $56^{\circ} \mathrm{C}$ for $30 \mathrm{~min}$ in $200 \mu \mathrm{L}$ of AL buffer containing $20 \mu \mathrm{L}$ of proteinase $\mathrm{K}$ in sterile $1.5 \mathrm{~mL}$ nuclease-free tubes. Swabs were then vortexed for $15 \mathrm{~s}$ and carefully removed after squeezing out the liquid contained in them with a sterile glass rod into the tube. The remaining solution was incubated at $56^{\circ} \mathrm{C}$ for $30 \mathrm{~min}$. The manufacturer's blood extraction protocol was thereafter used. The DNA concentration in aliquots was quantified (NanoDrop 2000c/2000 spectrophotometer; Thermo Scientific, Waltham, MA, USA) and, if above $50 \mathrm{ng} / \mu \mathrm{L}$, they were homogenised to that concentration with RNase/DNase free water (Promega, Madison, WI, USA). DNA aliquots were preserved frozen at $-20^{\circ} \mathrm{C}$ until the PCR was performed. Sample cross-contamination during DNA extraction was excluded by including negative controls (nuclease-free water; Promega, Madison, WI, USA) every ten samples that were also tested by PCR. A screening assay was selected for the detection of C. burnetii DNA in samples based on the IS1111-based PCR. Positive samples were further analysed by coupling the PCR with hybridization with a specific probe by reverse line blotting (RLB) $[19,20]$. The resulting genotypes were further analyzed with InfoQuest ${ }^{\mathrm{TM}} \mathrm{FP} 4.50$ (BioRad, Hercules, CA, USA). Cluster analyses used the binary coefficient (Jaccard) and UPGMA (Unweigthed Pair Group Method Using Arithmetic Averages) to infer the phylogenetic relationships (Supplementary Figure S1).

\section{Results and Discussion}

We detected C. burnetii DNA-positive if qPCR cycle threshold (Ct) values were $<40.0$-in 79 of 816 spleen samples analysed (Table 2). In general, and considering overall all locations, Microtus arvalis was the species displaying the highest ratio of infection with C. burnetii $(10.8 \%$; $62 / 572)$ followed by A. sylvaticus $(8.7 \% ; 12 / 138)$, Crocidura russula $(7.7 \%$; $2 / 26)$ and $R$. rattus $(6.4 \% ; 3 / 47)$. The other micromammal species sampled were negative. One of the 130 vaginal swabs collected from $M$. arvalis females was qPCR positive $(0.8 \%$; 95\%CI: 0.1-4.2). Ten positive samples with Ct values $<35.0$ were analysed by RLB hybridization. Only a genotype II+ strain could be obtained in one $M$. arvalis from Northwest Spain. The acute disease antigen A ( $a d a A)$ gene-present in some $C$. burnetii strains causing acute $Q$ fever in humans [21] — was present in this genotype II+ strain. Genotype II+ has been previously reported in ticks (Slovak Republic), sheep (Germany, Spain) and humans (Italy) and it appears to be the most widely distributed (RLB) genotype in Europe [19]; nevertheless, the absence of molecular epidemiology studies in wildlife and in particular in micromammals makes the understanding of potential cross-species transmission difficult. Typing pathogens circulating in healthy wildlife could be partly constrained by pathogen burden in tissues $[18,19]$. This may occur more frequently in enzootic pathogens that have a large history of co-evolution with their hosts and replicate at a lower ratio in hosts than epidemic pathogens [22]. This, however, does not detract these hosts from playing relevant roles in the life cycle of pathogens. Currently, no clinical consequence of C. burnetii infection has been reported or noticed in infected micromammals; none of the micromammals surveyed in this study had symptoms compatible with Coxiellosis. A significant number of the infected individuals did indeed display very low levels of $C$. burnetii DNA in the spleen (69 of the 79 qPCR-positives had Ct values close to the negative threshold), perhaps 
indicative of past or subclinical infections. We did indeed obtain partial RLB typing results for a major part of the analysed samples, but only one could be completely typed.

In recent decades, zoonotic emerging infectious diseases have advanced positions to become one of the most worrisome threats to human, livestock and wildlife health [23,24]; SARS-CoV-2 has an animal origin, and it has been able to cross the inter-species barrier to emerge as the most devastating human pandemic of our time [25]. This may be owed to changes in the patterns of interaction between domestic animals, wildlife and humans [4] that are most probably occurring due to human influences on habitats, biodiversity and the climate. These changing patterns may also be behind the re-emergence of enzootic zoonoses such as $Q$ fever that, although with a lower pandemic potential, may become a serious health problem. Our study contributes to unravelling the potential future threats of the re-emergence of $C$. burnetii infections of wildlife origin by informing about the potential implication of micromammals in the interspecific exchange of the pathogen. It also highlights the relevance of opportunistic sample collection in providing basic descriptive information useful to design future epidemiological studies. Findings reveal the occurrence of infections by C. burnetii in different species of wild micromammals in Spain as well as the presence of genotypes shared with humans, ticks and domestic animals and reported in different European countries [18,19].

In previous European studies, C. burnetti DNA was found in spleen samples of $R$. rattus, R. norvegicus, Mus musculus, A. flavicollis and A. sylvaticus from Cyprus, Germany, The Netherlands, Italy, Slovakia and Spain (Table 3). Prevalence ratio in medium-to-large sized studies ranged $0.6-23.5 \%$. Other micromammal species such as the bank vole, the common vole and the common shrew that were object of medium-to-large surveys did not show infection with C. burnetii.

Table 3. Review of current evidences of Coxiella burnetii DNA detection in European micromammal species.

\begin{tabular}{|c|c|c|c|c|}
\hline Common Name & Scientific Name & Country & Pos/N (Prev) & Reference \\
\hline \multirow{7}{*}{ Bank vole } & \multirow{7}{*}{ Myodes glareolus } & Austria & $0 / 40(0.0)$ & [26] \\
\hline & & Croatia & $0 / 43(0.0)$ & [27] \\
\hline & & Italy & $0 / 42(0.0)$ & [28] \\
\hline & & \multirow[b]{2}{*}{ Slovakia } & $0 / 23(0.0)$ & [29] \\
\hline & & & $0 / 239(0.0)$ & {$[30]$} \\
\hline & & Spain & $0 / 6(0.0)$ & [31] \\
\hline & & Czech Republic/Germany & $0 / 78(0.0)$ & {$[32]$} \\
\hline \multirow{2}{*}{ Black rat } & \multirow{2}{*}{ Rattus rattus } & Netherlands & $5 / 166(3.0)$ & {$[6]$} \\
\hline & & Spain & $3 / 47(6.4)$ & This study \\
\hline \multirow[b]{2}{*}{ Brown rat } & \multirow{2}{*}{ Rattus norvegicus } & Germany & $7 / 524(1.3)$ & [8] \\
\hline & & Netherl. & $8 / 164(4.8)$ & [6] \\
\hline \multirow{2}{*}{ Brown/black rat } & \multirow{2}{*}{ Rattus spp. } & Cyprus & $32 / 136(23.5)$ & [33] \\
\hline & & Spain & $3 / 3(100.0)$ & {$[20]$} \\
\hline \multirow{7}{*}{ Common vole } & \multirow{7}{*}{ Microtus arvalis } & Austria & $0 / 15(0.0)$ & [26] \\
\hline & & Croatia & $0 / 4(0.0)$ & [27] \\
\hline & & Germany & $0 / 109(0.0)$ & [34] \\
\hline & & \multirow{2}{*}{ Slovakia } & $0 / 3(0.0)$ & [29] \\
\hline & & & $0 / 19(0.0)$ & [30] \\
\hline & & Czech Republic/Germany & $0 / 148(0.0)$ & [32] \\
\hline & & Spain & $62 / 572(10.9)$ & This study \\
\hline Eurasian Harvest Mouse & Micromys minutus & Slovakia & $0 / 1(0.0)$ & {$[30]$} \\
\hline European Pine Vole & Microtus subterraneus & Slovakia & $0 / 1(0.0)$ & {$[30]$} \\
\hline \multirow{2}{*}{ European Water Vole } & \multirow{2}{*}{ Arvicola terrestris } & Spain & $0 / 1(0.0)$ & This study \\
\hline & & Germany & $0 / 3(0.0)$ & [34] \\
\hline \multirow{2}{*}{ Field vole } & \multirow{2}{*}{ Microtus agrestis } & Croatia & $0 / 1(0.0)$ & [27] \\
\hline & & Czech Republic/Germany & $0 / 1(0.0)$ & [32] \\
\hline
\end{tabular}


Table 3. Cont

\begin{tabular}{|c|c|c|c|c|}
\hline Common Name & Scientific Name & Country & Pos/N (Prev) & Reference \\
\hline Hazel dormouse & Muscardinus avellanarius & Croatia & $0 / 1(0.0)$ & [27] \\
\hline \multirow{3}{*}{ House mouse } & \multirow{3}{*}{ Mus musculus } & Spain & $2 / 28(7.1)$ & [31] \\
\hline & & Spain & $8 / 61(13.1)$ & [35] \\
\hline & & Spain & $0 / 10(0.0)$ & This study \\
\hline \multirow{9}{*}{ Long-tailed field mouse } & \multirow{9}{*}{ Apodemus sylvaticus } & Austria & $0 / 26(0.0)$ & [26] \\
\hline & & Croatia & $0 / 3(0.0)$ & [27] \\
\hline & & Italy & $2 / 101(19.8)$ & [28] \\
\hline & & & $0 / 3(0.0)$ & [29] \\
\hline & & Slovakia & $0 / 3(0.0)$ & [30] \\
\hline & & Czech Republic/Germany & $0 / 6(0.0)$ & [32] \\
\hline & & Germany & $0 / 2(0.0)$ & [34] \\
\hline & & Spain & $1 / 162(0.6)$ & [31] \\
\hline & & Spain & $12 / 138(8.7)$ & This study \\
\hline \multirow{2}{*}{ Striped Field Mouse } & \multirow{2}{*}{ Apodemus agrarius } & Croatia & $0 / 54(0.0)$ & [27] \\
\hline & & Czech Republic/Germany & $0 / 2(0.0)$ & [32] \\
\hline \multirow{8}{*}{ Yellow-necked field mouse } & \multirow{8}{*}{ Apodemus flavicollis } & \multirow{8}{*}{$\begin{array}{c}\text { Slovakia } \\
\text { Czech Republic/Germany } \\
\text { Germany } \\
\text { Spain } \\
\text { Spain }\end{array}$} & $0 / 29(0.0)$ & [26] \\
\hline & & & $0 / 131(0.0)$ & [27] \\
\hline & & & $1 / 38(2.6)$ & [29] \\
\hline & & & $0 / 401(0.0)$ & [30] \\
\hline & & & $0 / 48(0.0)$ & [32] \\
\hline & & & $0 / 3(0.0)$ & {$[34]$} \\
\hline & & & $0 / 3(0.0)$ & [31] \\
\hline & & & $0 / 2(0.0)$ & This study \\
\hline Common Shrew & Sorex araneus & Czech Republic/Germany & $0 / 30(0.0)$ & {$[32]$} \\
\hline Crowned Shrew & Sorex coronatus & Czech Republic/Germany & $0 / 7(0.0)$ & [32] \\
\hline Eurasian Pygmy Shrew & Sorex minutus & Czech Republic/Germany & $0 / 1(0.0)$ & {$[32]$} \\
\hline White-toothed Shrew & Crocidura russula & Spain & $2 / 26(7.7)$ & This study \\
\hline
\end{tabular}

European studies on C. burnetii have mainly focused on the most widespread and abundant micromammal species in Europe such as A. sylvaticus, Myodes glareolus, A. flavicollis, $M$. arvalis and Rattus sp. The genus Rattus has been found consistently positive to C. burnetii DNA in all the studies performed in Europe, so rats are currently considered as true $C$. burnetii reservoirs $[6,8,9]$. Coxiella burnetii DNA was also detected in $R$. rattus in southern Spain in this study, so rats can be relevant hosts for $C$. burnetii in the Iberian Peninsula as well. These may play also a relevant role in the exchange of $C$. burnetii at the wildlife-livestock-human interface because rats live in natural, peridomestic and urban environments. In most of the studies in which C. burnetii DNA has been detected in micromammals, these were captured in peridomestic areas where domestic ruminants (known C. burnetii reservoirs) were present. The micromammals surveyed for this study came from wild environments where the direct interaction with domestic ruminants is low or inexistent. Wild ungulates and other proven wild reservoirs of C. burnetii $[13,14]$ may be frequent in some of these areas but have been found to host mainly strains of the genotypes I and VII [19]. Our results cannot confirm that all the qPCR positive micromammal species found in this study are reservoirs for C. burnetii, but qPCR positive uterus samples from common voles were previously found [19] and a positive vaginal swab from $M$. arvalis was also found in this study, therefore demonstrating that $M$. arvalis is able to replicate and shed C. burnetii. An additional observation supporting the potential reservoir role of $M$. arvalis was the diagnosis of acute $Q$ fever in one of the researchers (and author in this study) that participated in the survey of common voles. This person presented to a local medical practitioner in April 2012 with high fever and malaise a week after finishing a vole survey in northwestern Spain, and it was presumably diagnosed with flu. Some days later, the patient had persistent high fever and visited a hospital in northern Spain where $Q$ fever was confirmed by detecting high titres (1/320) of specific C. burnetii IgG antibodies in an indirect immunofluorescent assay (IFA) and by a positive result in a specific IgM ELISA test for C. burnetii. The patient was negative to brucellosis, Lyme disease, tularaemia, 
bartonellosis and hepatitis B in a differential diagnosis approach of the probable infectious causes of persistent fever in a patient exposed to wildlife. This person had no history of exposure to livestock and other wildlife environments and had spent several weeks surveying voles before the onset of the symptoms. Whether this case was related to vole handling or was the consequence of exposure to contaminated aerosols from livestock or other wildlife shedding C. burnetii could not be determined.

The potential implication of Spanish micromammal species in the ecology of C. burnetii is based on some of the findings (in this and in other studies) such as the detection of specific C. burnetii antibodies in a wide diversity of micromammal species, including common vole, rats, house mouse, wood mouse and yellow-necked field mouse [4] that demonstrate susceptibility to pathogen infection. Further support comes from finding C. burnetii DNA in spleen samples of some micromammal species that indicates that a bacteraemia following replication did occur. In addition, C. burnetii DNA was found in the reproductive tract and vaginal secretions of $M$. arvalis, further supporting a potential efficient role in C. burnetii replication and transmission. The detection of C. burnetii DNA in rat faeces in other studies [36] also points out that (at least) rats also allow replication of $C$. burnetii and shedding.

The common vole experiences cyclic population density peaks under highly favourable environmental conditions that do indeed drive the exchange of zoonotic multi-host pathogens at the wildlife-human interface, e.g., Francisella tularensis [16]. However, in contrast to the spill-over role that $M$. arvalis plays in the transmission of $F$. tularensis, it may play a true reservoir role for $C$. burnetii and maintain it independently from the co-occurrence of other relevant hosts, e.g., lagomorphs or ungulates. Tularaemia is an emerging disease that currently is present only in the northern half of mainland Iberian Peninsula where it affects humans, wild lagomorphs and micromammals [37]. In this study, we observed in common voles from this area a slight increase in C. burnetii infection prevalence (unpublished data) from 2012 (low vole abundance) to 2014 (vole density peak in the study area; [38]), demonstrating persisting pathogen prevalence under conditions of contrasted host density (up to 100-fold), and supporting its role as true reservoir in clear contrast with tularaemia that practically disappears from vole populations in low abundance years [16]. During vole population outbreaks, infection rates and environmental contamination with C. burnetii could peak, given extremely high abundance of voles around or even inside villages, which could increase $Q$ fever and Coxiellosis risks for humans and animals, respectively. This may be perhaps partly reflected in the observed higher incidence of Coxiellosis in sheep farms [39] during years of high vole density (2010-2011) in the region where M. arvalis were surveyed for this study [38]. C. burnetii transmission to livestock could be relevant in years or areas with high density of voles, but more precise information and longer time series should be required to confirm this possibility and any potential link among voles and domestic ruminants in C. burnetii exchange. The human infection case reported above indicates that frequent and tight contact with $M$. arvalis is a risk factor potentially promoting $\mathrm{Q}$ fever, so recommendations about avoiding contact with these animals disseminated to rural populations in vole outbreak years are highly advisable. The participation of potential coexisting micromammal reservoir species, e.g., A. sylvaticus and C. russula, would add complexity to understanding the factors shaping C. burnetii transmission risks in a sylvatic cycle [16]. Thus, sanitary recommendations to avoid contact with small mammals should be extended in general terms in the Iberian Peninsula.

\section{Conclusions}

We can conclude that this first approach provides evidence supporting the fact that there are several micromammal species that can be potential reservoirs of $C$. burnetii. Abundant and widespread species in the Iberian Peninsula, e.g., rats, wood mouse and white-toothed shrew, as well as species experiencing drastic cyclic demographic outbreaks, i.e., the common vole, might be relevant in the maintenance of wild-type $C$. burnetii strains that can be a matter of concern for animal and human health authorities. 
Supplementary Materials: The following files are available online at https:/ / www.mdpi.com/2076 -2615/11/3/654/s1, Figure S1: Dendrogram construct from hybridization data of 1 sample from this study (@), samples from González-Barrio et al. [19] and reference strains (framed text). Biological and geographic origin of the samples is displayed. Black boxes indicate the presence of the selected ORFs. Coxiella burnetii reference isolates used to validate the method are framed. * Acute disease antigen A gene $(a d a A) ;+$, Presence of $a d a A ;-$, Absence of $a d a A$.

Author Contributions: Conceptualization, D.G.-B., J.V., J.T.G. and F.R.-F.; methodology, D.G.-B., I.J., J.V., J.T.G., P.P.O., F.A. and F.R.-F.; software, D.G.-B.; validation, D.G.-B., I.J. and F.R.-F.; formal analysis, D.G.-B. and F.R.-F.; investigation, D.G.-B. and F.R.-F.; resources, J.V., J.T.G., I.J. and F.R.-F.; data curation, D.G.-B., J.T.G., F.A. and F.R.-F.; writing-original draft preparation, D.G.-B. and F.R.-F.; writing-review and editing, D.G.-B., I.J., J.V., J.T.G., P.P.O., F.A. and F.R.-F.; supervision, D.G.-B. and F.R.-F.; project administration, D.G.-B., J.V., J.T.G. and F.R.-F.; funding acquisition, J.V., J.T.G. and F.R.-F. All authors have read and agreed to the published version of the manuscript.

Funding: This work was supported by grants CGL2011-30274 and CGL2015-71255-P of the Spanish Ministry for the Science and Innovation (MCI), and by the 'Fundación BBVA' Research Project TOPIGEPLA (2014 call). This is also a contribution to MCI-funded projects CGL2017-89866-R and E-RTA-2015-0002-C02-02. D.G.-B. was funded by MCI through Juan de la Cierva (FJCI-2016-27875) and 'Sara Borrell' (CD19CIII/00011) postdoctoral fellowships. GREFA provided partial financial support and invaluable logistic and workforce support for samplings in NW Spain, along with many students and staff from UAM.

Institutional Review Board Statement: The study was conducted according to the guidelines of the Declaration of Helsinki, and approved by UCLM Ethics Committee (reference number CEEA: PR20170201, date of approval: 15 March 2017).

Data Availability Statement: The data presented in this study are available in this article and Supplementary Material (Figure S1).

Acknowledgments: The authors extend particular thanks to Ana Benítez López, María Calero Riestra, Paqui Talavera, Iván García Egea, Jesús Herranz, Daniel Jareño Gómez, Salvador Luna, Julian Núñez Conde, Juan Oñate, Alfonso Paz Luna, Francisco Díaz Ruiz, Fernando Garcés, Carlos Cuellar, Fernando Blanca Chana, Lorena Hernández and Xurxo Piñeiro Álvarez.

Conflicts of Interest: The authors declare no conflict of interest.

\section{References}

1. Angelakis, E.; Raoult, D. Q fever. Vet. Microbiol. 2011, 140, 297-309. [CrossRef] [PubMed]

2. Maurin, M.; Raoult, D. Q fever. Clin. Microbiol. Rev. 1999, 12, 518-553. [CrossRef]

3. EFSA. The European Union summary report on trends and sources of zoonoses, zoonotic agents and food-borne outbreaks in 2012. EFSA J. 2014, 12, 3547.

4. González-Barrio, D.; Ruiz-Fons, F. Coxiella burnetii in wild mammals: A systematic review. Transbound. Emerg. Dis. 2019, 66, 662-671. [CrossRef]

5. Toledo, A.; Jado, I.; Olmeda, A.S.; Casado-Nistal, M.A.; Gil, H.; Escudero, R.; Anda, P. Detection of Coxiella burnetii in ticks collected from central Spain. Vector Borne Zoonotic Dis. 2009, 9, 465-468. [CrossRef]

6. Meerburg, B.G.; Reusken, C.B.E.M. The role of wild rodents in spread and transmission of Coxiella burnetii needs further elucidation. Wildl. Res. 2011, 38, 617-625. [CrossRef]

7. Reusken, C.; van der Plaats, R.; Opsteegh, M.; de Bruin, A.; Swart, A. Coxiella burnetii (Q fever) in Rattus norvegicus and Rattus rattus at livestock farms and urban locations in the Netherlands; could Rattus spp. represent reservoirs for (re)introduction? Prev. Vet. Med. 2011, 101, 124-130. [CrossRef] [PubMed]

8. Runge, M.; Von Keyserlingk, M.; Braune, S.; Becker, D.; Plenge-Bönig, A.; Freise, J.F.; Pelz, H.-J.; Esther, A. Distribution of rodenticide resistance and zoonotic pathogens in Norway rats in Lower Saxony and Hamburg, Germany. Pest. Manag. Sci. 2013, 69, 403-408. [CrossRef] [PubMed]

9. Izquierdo-Rodríguez, E.; Fernández-Álvarez, Á.; Martín-Carrilo, N.; Feliu, C.; Marchand, B.; Quilichini, Y.; Foronda, P. Rodents as Reservoirs of the Zoonotic Pathogens Coxiella burnetii and Toxoplasma gondii in Corsica (France). Vector Borne Zoonotic Dis. 2019, 19, 879-883. [CrossRef] [PubMed]

10. European Centre for Disease Prevention and Control. Q fever. In ECDC. Annual Epidemiological Report for 2018; ECDC: Stockholm, Sweden, 2019.

11. Ruiz-Fons, F.; Astobiza, I.; Barandika, J.F.; Hurtado, A.; Atxaerandio, R.; Juste, R.A.; García-Pérez, A.L. Seroepidemiological study of $Q$ fever in domestic ruminants in semi-extensive grazing systems. BMC Vet. Res. 2010, 6, 3. [CrossRef] 
12. González-Barrio, D.; Almería, S.; Caro, M.R.; Salinas, J.; Ortíz, J.A.; Gortázar, C.; Ruiz-Fons, F. Coxiella burnetii shedding by farmed red deer (Cervus elaphus). Transbound. Emerg. Dis. 2015, 62, 572-574. [CrossRef]

13. González-Barrio, D.; Velasco Ávila, A.L.; Boadella, M.; Beltrán-Beck, B.; Barasona, J.A.; Santos, J.P.V.; Queirós, J.; García-Pérez, A.L.; Barral, M.; Ruiz-Fons, F. Host and environmental factors modulate the exposure of free-ranging and farmed red deer (Cervus elaphus) to Coxiella burnetii. Appl. Environ. Microbiol. 2015, 81, 6223-6231. [CrossRef]

14. González-Barrio, D.; Maio, E.; Vieira-Pinto, M.; Ruiz-Fons, F. European rabbits as reservoir for Coxiella burnetii. Emerg. Infect. Dis. 2015, 21, 1055-1058. [CrossRef] [PubMed]

15. Jareño, D.; Viñuela, J.; Luque-Larena, J.J.; Arroyo, L.; Arroyo, B.; Mougeot, F. Factors associated with the colonization of agricultural areas by common voles Microtus arvalis in NW Spain. Biol. Invasions 2015, 17, 2315-2327. [CrossRef]

16. Luque-Larena, J.J.; Mougeot, F.; Arroyo, B.; Vidal, M.D.; Rodríguez-Pastor, R.; Escudero, R.; Anda, P.; Lambin, X. Irruptive mammal host populations shape tularemia epidemiology. PLoS Pathog. 2017, 13, e1006622. [CrossRef]

17. Navarro, L.M.; Pereira, H.M. Rewilding abandoned landscapes in Europe. Ecosystems 2012, 15, 900-912. [CrossRef]

18. González-Barrio, D.; Hagen, F.; Tilburg, J.J.H.C.; Ruiz-Fons, F. Coxiella burnetii genotypes in Iberian wildlife. Microb. Ecol. 2016, 72, 890-897. [CrossRef]

19. González-Barrio, D.; Jado, I.; Fernández-de-Mera, I.G.; Fernández-Santos, M.R.; Rodríguez-Vargas, M.; García-Amil, C.; BeltránBeck, B.; Anda, P.; Ruiz-Fons, F. Genotypes of Coxiella burnetii in wildlife: Disentangling the molecular epidemiology of a multi-host pathogen. Environ. Microbiol. Rep. 2016, 8, 708-714. [CrossRef]

20. Jado, I.; Carranza-Rodríguez, C.; Barandika, J.F.; Toledo, A.; García-Amil, C.; Serrano, B.; Bolaños, M.; Gil, H.; Escudero, R.; García-Pérez, A.L.; et al. Molecular method for the characterization of Coxiella burnetii from clinical and environmental samples: Variability of genotypes in Spain. BMC Microbiol. 2012, 12, 91. [CrossRef]

21. Frangoulidis, D.; Splettstoesser, W.D.; Landt, O.; Dehnhardt, J.; Henning, K.; Hilbert, A.; Bauer, T.; Antwerpen, M.; Meyer, H.; Walter, M.C.; et al. Microevolution of the chromosomal region of acute disease antigen A (adaA) in the query (Q) fever agent Coxiella burnetii. PLoS ONE 2013, 8, e53440. [CrossRef] [PubMed]

22. Casades-Martí, L.; González-Barrio, D.; Royo-Hernández, L.; Díez-Delgado, I.; Ruiz-Fons, F. Dynamics of Aujeszky’s disease virus infection in wild boar in enzootic scenarios. Transbound. Emerg. Dis. 2020, 67, 388-405. [CrossRef]

23. Gortazar, C.; Reperant, L.A.; Kuiken, T.; de la Fuente, J.; Boadella, M.; Martínez-Lopez, B.; Ruiz-Fons, F.; Estrada-Peña, A.; Drosten, C.; Medley, G.; et al. Crossing the interspecies barrier: Opening the door to zoonotic pathogens. PLoS Pathog. 2014, 10, e1004129. [CrossRef] [PubMed]

24. Ruiz-Fons, F. A review of the current status of relevant zoonotic pathogens in wild swine (Sus scrofa) populations: Changes modulating the risk of transmission to humans. Transbound. Emerg. Dis. 2017, 64, 68-88. [CrossRef] [PubMed]

25. Latif, A.A.; Mukaratirwa, S. Zoonotic origins and animal hosts of coronaviruses causing human disease pandemics: A review. Onderstepoort J. Vet. Res. 2020, 87, e1-e9. [CrossRef] [PubMed]

26. Schmidt, S.; Essbauer, S.S.; Mayer-Scholl, A.; Poppert, S.; Schmidt-Chanasit, J.; Klempa, B.; Henning, K.; Schares, G.; Groschup, M.H.; Spitzenberger, F.; et al. Multiple infections of rodents with zoonotic pathogens in Austria. Vector Borne Zoonotic Dis. 2014, 14, 467-475. [CrossRef]

27. Tadin, A.; Tokarz, R.; Markotić, A.; Margaletić, J.; Turk, N.; Habuš, J.; Svoboda, P.; Vucelja, M.; Desai, A.; Jain, K.; et al. Molecular survey of zoonotic agents in rodents and other small mammals in Croatia. Am. J. Trop. Med. Hyg. 2016, 94, 466-473. [CrossRef] [PubMed]

28. Pascucci, I.; Domenico, M.D.; Dall'Acqua, F.; Sozio, G.; Camma, C. Detection of Lyme Disease and Q fever agents in wild rodents in Central Italy. Vector Borne Zoonotic Dis. 2015, 15, 404-411. [CrossRef] [PubMed]

29. Smetanova, K.; Schwarzová, K.; Kocianová, E. Detection of Anaplasma phagocytophilum, Coxiella burnetii, Rickettsia spp., and Borrelia burgdorferi s. 1. in ticks, and wild-living animals in Western and Middle Slovakia. Ann. N. Y. Acad. Sci. 2006, 1078, 312-315. [CrossRef]

30. Minichová, L.; Hamšíková, Z.; Mahríková, L.; Slovák, M.; Kocianová, E.; Kazimírová, M.; Škultéty, L.; Štefanidesová, K.; Špitalská, E. Molecular evidence of Rickettsia spp. in ixodid ticks and rodents in suburban, natural and rural habitats in Slovakia. Parasites Vectors 2017, 10, 158. [CrossRef]

31. Barandika, J.F.; Hurtado, A.; García-Sanmartín, J.; Juste, R.A.; Anda, P.; García-Pérez, A.L. Prevalence of tick-borne zoonotic bacteria in questing adult ticks from Northern Spain. Vector Borne Zoonotic Dis. 2008, 8, 829-835. [CrossRef] [PubMed]

32. Obiegala, A.; Jeske, K.; Augustin, M.; Król, N.; Fischer, S.; Mertens-Scholz, K.; Imholt, C.; Suchomel, J.; Heroldova, M.; Tomaso, H.; et al. Highly prevalent bartonellae and other vector-borne pathogens in small mammal species from the Czech Republic and Germany. Parasites Vectors 2019, 3, 332. [CrossRef] [PubMed]

33. Psaroulaki, A.; Chochlakis, D.; Angelakis, E.; Ioannou, I.; Tselentis, Y. Coxiella burnetii in wildlife and ticks in an endemic area. Trans. R. Soc. Trop. Med. Hyg. 2014, 108, 625-631. [CrossRef]

34. Pluta, S.; Hartelt, K.; Oehmeb, R. Prevalence of Coxiella burnetii and Rickettsia spp. In ticks and rodents in southern Germany. Ticks Tick-Borne Dis. 2010, 1, 145-147. [CrossRef] [PubMed]

35. Bolaños-Rivero, M.; Carranza-Rodríguez, C.; Rodríguez, N.F.; Gutiérrez, C.; Pérez-Arellano, J.L. Detection of Coxiella burnetii DNA in peridomestic and wild animals and ticks in an endemic region (Canary Islands, Spain). Vector Borne Zoonotic Dis. 2018, 61,30-33. 
36. Abdel-Moein, K.A.; Hamza, D.A. Rat as an overlooked reservoir for Coxiella burnetii: A public health implication. Comp. Immunol. Microbiol. Infect. Dis. 2017, 17, 630-634. [CrossRef] [PubMed]

37. Lopes de Carvalho, I.; Toledo, A.; Carvalho, C.L.; Barandika, J.F.; Respicio-Kingry, L.B.; Garcia-Amil, C.; García-Pérez, A.L.; Olmeda, A.S.; Zé-Zé, L.; Petersen, J.M.; et al. Francisella species in ticks and animals, Iberian Peninsula. Ticks Tick Borne Dis. 2016, 7, 159-165. [CrossRef] [PubMed]

38. Mougeot, F.; Lambin, X.; Rodríguez-Pastor, R.; Romairone, J.; Luque-Larena, J.J. Numerical response of a mammalian specialist predator to multiple prey dynamics in Mediterranean farmlands. Ecology 2019, 100, e02776. [CrossRef]

39. García-Seco, T. Epidemiología de la Fiebre Q en Rumiantes Domésticos en la Zona Central de la Península Ibérica. Ph.D. Thesis, Complutense University of Madrid, Madrid, Spain, 2017. 